\title{
African spirituality in transformation: Fragments and fractures of the shifting sacred
}

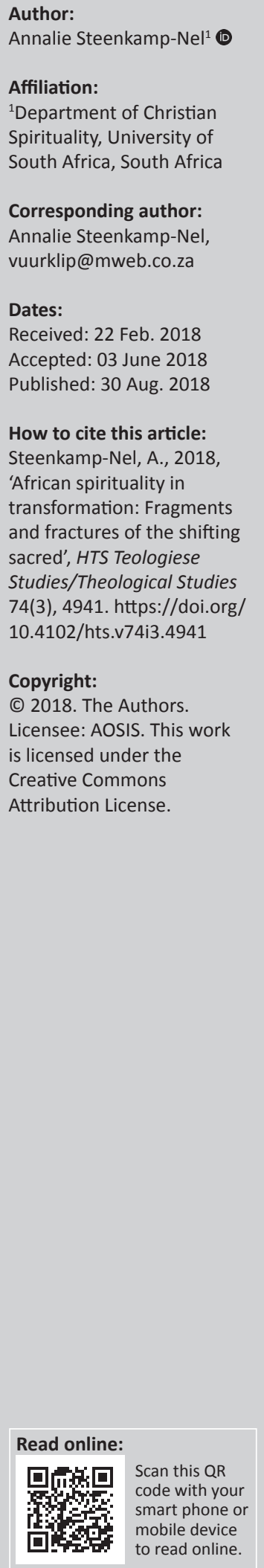

The 'transformation' of disciplines and organisations has been increasingly pursued by South African policymakers. Many understand community engagement or development as 'structural' or 'agentive'. For most African citizens, however, transformation's starting point is the obligation towards the divine and towards others. It will be suggested that spiritual transformation (as an aspect of African spirituality) is more appropriate for the South African setting. The article will offer the overarching foundational spiritual framework of spiritual transformation as a possible object to a future discourse. A literature review will allow the mapping of different transformational stages or movements. The dynamics of the African spiritual-based concept of joy as a bridge to new possibilities will be tracked. The findings will point to the importance of clashing or complementing spiritual experiences, directing Africans towards a new spirituality. It will be indicated how change agents can develop sustainable transformative methodologies for different contexts, relevant to the developmental challenges of communities and organisations. Successful transformation involves nurturing communities from a spiritual perspective, specifically the experience of joy as part of the original African spirituality.

\section{Introduction}

'Transformation' has become a popular buzzword in many sectors of post-apartheid South African society. From the public (Bender 2008:91; Department of Education 2002; Department of Education South Africa 1997; DPSA 1997; Waghid 2002:457-488) to the private sector (CANSA 2016a; Working Group 2012:11), from platforms (SACC 2017) to pulpits (Travis 2014:4, 63, 141) to the pews (Van Wyk 2017), and from the public treasury (National Treasury Republic of South Africa 2017:vii) to piggy banks (Iten 2016), industries are poked to crystallise transformation (Department of Tourism 2016:3-5, 17; Pieterse 2005:155-166). What is 'transformation'?

'Transformation' in Africa (Kelkil 2015:2; Tesagaye \& Sewenet 2017:347, 350-351) and by South African policymakers has been ex cathedra perceived as social-political (Lombaard 2015; Spies 2010:14), and socio-economic transformation (Clarke \& Basset 2016:183-186). Various scholars (Chipkin 2008:132; Desai 2008:325; Morrow 2008:267; Naidoo 2008:120) and institutions (Hoppers 2012:1-4; National Treasury Republic of South Africa 2017:1) like universities (Hoppers 2010:8788; Letsekha 2013:5-7) and organisations or non-profit organisations (NPOs) (CANSA 2016b; Nauta 2004:169, 262) interpret transformation or development as 'structural' (Nauta 2004:264) or agentive. An 'agent' is a bounded, but not determined individual who can alter structures through practice (or praxis). 'Structure' is the larger, more perduring settings and conditions that result from the ongoing relationships between individuals (Dornan 2002:305). In general, the above phenomenon of (individual) agency and structuration theory is often viewed as a panacea to achieve redress in South Africa. The agentive approach reflects an agreement, reaction and desire to counter the 'deep moral, social and economic scars' (Nauta 2004:150) afflicted and effected by the previous South African deterministic political dispensation. The current transformation agenda's purposeful, intentional actions and alterations (follow Hoppers 2010:89-90) are, however, narrow, limited and less inspiring, considering that it is already, and also a gradual receding from $U b u n t u^{1}$ as well as a chimera - when not taking into account and owning the failures of transformation's design. Firstly, Jones (2000:445-457), Naidoo (2008:119) and Van der Linde-de Klerk, Martin and de Beer (2014:93-115) state the boundedness of agents' skills and knowledge. In the second place, Agbiji and Swart (2015:13) and Nauta $(2004: 166,169,173)$ emphasise the limits of ideology. Thirdly, Swartz and Davies (1997: 293) draw attention to the effect of mass urbanisation. Also noteworthy is internal contradictions raised by financial concerns (Nauta 2004:251-253).

1.Ubuntu is an African philosophy of, namely, a 'caring society' based on relationship with God (and unseen realities), fellow humans and nature (Masango 2006:108; Mokgoro 1998:8, 9). Not exclusive to Africa (Makhubela 2016:9; Somni \& Sandlana 2014), it shows directionality towards peripheral ideas (outside the individual) or the collective. 
There is no doubting the influence of community dynamics (Nauta 2004:172, 262). Subsequently, religious nonchalance and indifference can weaken resolve (Agbiji \& Swart 2015:8). The sixth is competition for power, resources (Nauta 2004:262) and consequently social status (Agbiji \& Swart 2015:14), and finally, antithetical value systems like collective societies' absence of self-critique (Appadurai \& Breckenridge 2008:352). Even so, the boundedness of the construct does not altogether eclipse the practical value of transformation. On the contrary, authors use transformation exactly in the place where they seek to conceptualise spirituality (Waaijman 2002:455). The potential for transformation lies hitherto in the domain of spirituality (Tobler 2002:51). Follow Lama and Tutu (2016:4, 106, 147, 161, 197, 286, 325, 345), Vilakati, Shcurink and Viljoen (2013:1) and Tutu (1999:229, 265).

Because an etic perspective can attune one to relationships between external structural variables and behaviours, I hope to - instead of generalities - present a more functionalist version of transformation (follow Morris et al. 1999:790). In the light of assumptions that it is possible to structure (Grant 2007:16,17,18) and legislate transformation, following the continued faith, and investment placed in stakeholders' transformatory potential, this article seeks to explore and consider a theoretical framework of spiritual transformation in the context of African spirituality (Brown 2010:173). Finally, the opportunities rendered by joymotion will be explored. This will be followed by a discussion on the inherently overlapping stages or movements of African spiritual transformation.

I should add here a few explanatory notes before the discussion. Spiritual transformation is the process of restoration of the divine-human relationship. It goes one step further than transformation on its own: rather, it is transformation by God leading to unlimited possibilities (Rahner 1984:61). I would like to preface this article by stating that I adopt an etic perspective (that of an outsider looking in) as I am not a member of the African culture. I endeavour to discuss - with a degree of humility - the main tenets underpinning African spirituality. In addition, although the Bible holds a central place in contemporary African Christian life and thought (Mwombeki 2001:121-128), it is the general take of this article that African Christian spirituality is still rooted in African spirituality (Froise 2005:56-59; Van Dyk \& Nefale 2005:52). Most Africans 'are still being influenced by, and experience the deep-rooted African traditional believes to an extent' (Knoetze 2015). The core argument in the article is that what matters to Africans is not so much the hype around transformation. Rather, the article contends that spiritual transformation precedes a relevant transformation agenda.

\section{Tides and transformations}

The tides and times are turning. As circumstances change, people change with it. Before I explore how people change, it will be conducive to take note of the outer horizon. Waaijman (2007:3) distinguished two horizons: an outer and inner horizon. The outer horizon is a person's historical, socio-psychological, economic and cultural environments. The inner horizon is spiritual transformational experience such as virtues and prayer practices (Van den Hoogen 2011:101; Waaijman 2002:3). The South African society stands, regarding the inner horizon, currently between the tidelands. As Lombaard notes: 'Spirituality never stands detached from, and is conditioned by, the culture or society in which it is expressed' (Lombaard 2012:163). The primeval African sage, Hermes Trismegistus' words are fitting:

Everything flows, out and in; everything has its tides; all things rise and fall; the pendulum-swing manifests in everything; the measure of the swing to the right is the measure of the swing to the left; rhythm compensates. (Three Initiates 1912:33)

There are two parallel tides on African spiritual transformation. Firstly, the traditionalists are of the opinion that personal commitment and responsibility, and therefore spiritual transformation, are embedded in what I call spiritual centrifugality. Spiritual centrifugality communicates collaboration, exchanges information and distributes accumulated group knowledge (see Sapir 1963:49) based on care and shared concern (Sachs 1992:64, 174), for instance, Ubuntu (Tlhagale 2011:21) and several rites of passage (Masango 2006:113). Rites of passage such as circumcision, marriage and burials shape the African person through sharing of experiences in order to live harmoniously with others (Masango 2006:113). According to this view, because of Africans' personal understanding that all humans are interconnected (Sigger, Polak \& Pennink 2010:55), they find it easy to be compassionate towards other human beings. This community orientation is, according to Masango (2006:113), based on the assumption that 'African people have no private faith or private spirituality', and that 'the individual identity of an African almost does not exist' (Theletsane 2012:271). This view is still prevalent in South Africa.

In the second view, the restorers of Ubuntu argue that recent social upheaval led to the unravelling and subsequent breakdown of Ubuntu (Masango 2006:113). For a more complete picture of critique on Ubuntu, follow Mzondi (2012) and Murithi (2006:14). The desire is to return to Ubuntu in order to rebuild and revitalise the community (Masango 2006:942; Theletsane 2012:276-277). For these af(r)icionados, ${ }^{2}$ the spirit of Ubuntu (as a transformational vehicle or an agent) will help the nation 'to find a new identity which will transcend the ethnic divisions that haunt the African continent' (Mbigi \& Maree 1995:9). To transform back to Ubuntu is to rebuild the nation to its original way of living, and respecting each other as being done before' (Masango 2006:942).

Taking into consideration that the above traditionalists and restorers provide a rich tableau to aid change, it is also of importance to note that they in addition contribute to the

2.An aficionado is a person who is very knowledgeable and enthusiastic about an activity, subject or pastime (Stevenson 2010:28). An af(r)icionado can be a person
who is very knowledgeable and enthusiastic about returning to African values like who is very
Ubuntu. 
perception that African spirituality is stagnant or obsolete. By 'harking back to a time before mass urbanisation' (Swartz \& Davies 1997:293) these views result in leaping over the following tidal markers. One is that Ubuntu's after-effect is not a very positive zezindwangu [isiZulu], lappieskombers [Afrikaans] or quilt (follow Neocosmos 2006; Ramphele 2008:117, 176, 298; Thomas 2009:51, 53; United Nations Development Programme 2003). Another is that Ubuntu does not automatically guarantee change (Swartz \& Davies 1997:293). In the third place, Ubuntu in modern times has to be 'more explicit' (Thomas 2009:57). Fourthly, this incidentally takes care of the fact that there is an urgency for creative thinking (Thomas 2009:52, 57). Fifthly, there is a lack of processuality in the discourse on African spirituality, and therefore a necessitas for a spiritual process 'that (can) hold African spirituality together' (Muto 2011:93).

To be able to hold humanity and Africa together, I will follow the advice of Masango (2006:113), namely to dig deep(er) 'into the African concept of spirituality'. I will offer a next level of how spirituality could contribute towards fostering a more relevant transformation agenda in Africa (Agbiji \& Swart 2015:16) by adding in the vein of African spirituality's hermetic heritage a third angle, namely African spirituality as a transformative process. The goal of the article is to harmonise the outgoing and incoming tide. So, how can and do Africans transform spiritually?

\section{African spiritual transformation: The shifting sacred}

So far we have focused on the different interpretations of African transformation. Lifting our gaze to the global horizon (Makhanya 2011:5), it is important to note that this discussion takes place amidst a gradual recrudescence of transformation in religious institutions worldwide (Harless 2012:10, 138, 139, 149, 151; Stetzer \& Rainer 2010), from the perspectives of architecture (Beliveau 1988; Kilde 2002), music (Chung \& Sawyer 2008:131-148), dance (Ragin, Farley \& Hoye 2008:81100), dramatic art (Farley 2008:61-80), visual arts (Dyrness 2008:10-114), film (Johnston 2008:115-130), tourism (Spenceley \& Goodwin 2007:256) and insect transgenesis (Atkinson \& O'Brochta 2000:229-232; Eggleston \& Zhao 2000:29-52). As African spirituality is flexible and in a process, which like the tides subtract (deduct or prune) and protract (to extend forward or outward) as time goes by, I will now focus on the individual aspect of spiritual transformation. In brief, most scholars are of the opinion that spirituality permeates almost every aspect of African life, and consider it as 'a crucial component of "Africaness"' (Agbiji \& Swart 2015:1, Magesa 1998:214; Knoop \& Fave 2013:98). A focus on African spirituality's transformative capacity is relatively new though (Falk 2001), and an emphasis on personal transformative capacities is untrodden waters. MacDonald's (2010) mirrors the influential take on transformation that is for 'Ubuntu ideals to be true, the collective process is as important as its collective product'. It is not a prerequisite though. Spiritual transformation can be viewed as a collective as well as a personal spiritual construct. Spirituality is, in fact, not static. It can flow in both directions, individually and collectively. Aburdene (2005) points out that this fast changing world is characterised by an increasing flow of spirituality from the personal to the institutional domains of life. Although some is of the opinion that (trans) formation in Africa cannot be vanguardist (MacDonald 2010:149), transformation is taking place in people's individual experiences.

Contrary to studies that assume that Africans do not focus on personal change (Nurnberger 2007:31, 44; Tlhagale 2011:21), there is substantial evidence that in order to overcome the dichotomy between the sacred and the profane, Africans acknowledge (concordant with spiritual centrifugality) spiritual centripetality (Falk 2001; Mugambi 1995:6, 39, 186). I might note here that spiritual centripetality is an individual's transformative capacity to not just act on the behest of his or her culture or environment, but to also actively examine and create his or her own domain of influence. Such persons have a separate spiritual identity and ontological status, above and beyond their surroundings, namely, that of the heavenly kingdom. Two sterling examples are the following. Firstly, Mosha (2000:50) emphasised the 'human predisposition and tendency in Africa to seek social, as well as personal moral transformation'. As Mercy Odoyuye (1999:19) attested: 'To participate (as an African childless woman theologian) in the ever-widening stream of resurrecting people is to know fruitfulness, to be transformed'. Secondly, the African theologian Mugambi (1995:11-14,15) noted that in order to redirect re-active liberation theology to pro-active personal reconstruction, individual renewal is needed. Ngong calls it 'inner transformation' (2010:47). It is fitting because spiritual transformation takes place on an individual level (before God). I distinguish between three types of spiritual transformation, following the work by Kees Waaijman, 'Spirituality: Forms, Foundations, Methods' (Dutch, 2000; English translation, 2002). They are labelled deformation, reformation and transformation. Deformation is conformity to the world. One has no prospects or hope, and is limited by people or situations or yourself, self-orientated and/or self-absorbing (Waaijman 2006:44, 460, 461). Reformation proceeds from God and entails a renewal of the mind to distinguish what is good, distinguishable by action. Transformation entails being orientated towards, dissolved in and conformed to divine reality (Waaijman 2002:456, 517). Spiritual transformation is not linear. It is a process, and individuals can oscillate between ecstasy and confusion, a feeling of nothingness, but also triumph (Steenkamp-Nel 2018). Finally, from a communal or national perspective, Yontef observed that for a 'nation to individuate, it is necessary for people to individuate' (Yontef 1993:183). As Huls (2006) pointed out so eloquently:

We can no longer return to what we had learned. Then it is no longer possible to hide ourselves behind others. We will have to give a personal answer with regard to the vital questions we are confronted with. (p. 68) 
So, Africans show us that the definition regarding the outer horizon should be broadened by adding obsolete beliefs. My reason being that when a person's religious convictions (which are supposed to transform the person) broaden or attenuate, so too does the person's inner horizon. According to the Africans above some of their traditional spiritual beliefs formed them, but no longer transformed them. It became or is stagnant, and therefore became or is their context. Ubuntu, for some, shifted to their outer horizon.

Spiritual centripetality, however, takes time. Mugambi confirmed the processual aspect of transformation: 'Process thought appreciates the perennial ebb and flow of human cultural and religious achievements' (1995:xv). A literature review will now allow the mapping of different transformational stages or movements regarding spiritual centripetality. I will first introduce ripples of deformation that allow us to be closer to the African experience. This will be followed by a discussion on reformation. Finally, a more pertinent exploration of the dynamics of 'joymotion' and how the realities of joy open up possibilities of growth will be explored. Finally, I will end the discussion by giving new consideration to the ways in which change agents can develop and utilise sustainable transformative methodologies for different contexts, relevant to the developmental challenges of communities and organisations.

\section{Fragments and fractures of deformation}

The racial rift that characterised South Africans' social and political outer horizon is increasingly fracturing into or shifting towards varied cross-cutting social identities (SchulzHerzenberg 2009:22), and value systems (Idang 2015:106-110) caused by democratisation (Schulz-Herzenenberg 2009:11,27), increased education and income, and newly adopted religious, class or occupational identities (Mattes 2004:8). This shift is causing a tidal wave of reactions or deformations, as observed by researchers. Citizens and corporations alternate, for instance, between ecstasy and depression (Gumede 2016), opaqueness and territoriality (Kumaran, Samuel \& Winston 2012:37), authoritarianism (Clarke \& Basset 2016), racialisation (Carrim \& Nkomo 2016:261-277; Schierup 2016: 276), denominationalism (Cilliers \& Nell 2011), impatient signals for social transformation (Bertelsmann Stiftung 2016:3; Schierup 2016:301), confrontational protests (Jili 2012), the recent re-localisation ${ }^{3}$ of identity, and re-valuing of indigenousness (Boswell 2016) made manifest through the African youth's unsettling escalating 'desire for change as well as a resistance to it' (Higgins 2016:5). It must indeed be disappointing from a governmental perspective to see a dream collapse. Why do South Africans not journey along the rainbow path (anymore)?

One reason is recent policies' 'value neutral' orientation (Conradie \& Pillay 2015:8). This concern over value

3.Relocalisation focuses on the reinforcement of local identity, and is often used as an economic and political resource; for example, the employment of 'local' staff (Kappler 2015:881). neutrality gives rise to the question: Did South Africans underestimate the spiritual aspect of transformation, or did social and political activists ask South Africans knowingly, and/or unknowingly, not just for 'economic and social compassion, but also for inner transformation' (Mooney 2014), namely to:

let go and shed layers of cultural sediment built up over time to allow the essence of our soul, our individual self, to emerge (as part of a lifelong process) from under the conventional and socially acceptable roles we play. (p. 119)

What does the African soul say? I will highlight just a few. A point of much concern is rootlessness ${ }^{4}$ (Mugisha et al. 2016:59, Woodhead 2007:18, 229, 251, 253, 256) coupled with anti-social behaviour (Ashforth 2000:232) amongst the African urban $^{5}$ middle classes (Krige 2015:105) combined with 'radical action with irresponsibility in their personal lives'. Higgins (2016) discovered through the eyes of a student:

I and my generation were without choice educated in a schooling environment that in its content orientated us away intellectually from our formative environments of home and community. This resulted in dangerously high levels of alienation as 'our affective imaginations progressively got anchored elsewhere', with the inevitable consequence that 'our own immediate world' became 'less real'. (pp. 4, 5)

This is echoed by Makhanya who states that a 'sense of isolation and alienation' is experienced by many academic colleagues at the universities (Mabokela 2012:129-134; Makhanya 2011:2; Potgieter \& Moleko 2004:80-95). Such individuals can be susceptible to deformation. From the psychology field, this dynamics is described as a 'split-ego experience' or 'mismatch syndrome' characterised by high levels of anxiety and resistance; fear of rejection; intense conflict between ambivalent feelings of loyalty and disloyalty, trust and distrust, group cohesion and separation individuation need; and diffused versus rigid group borders (more individualistic) and the traditional community (with its communalistic values), intense anxiety and fear of rejection by their community (Van Dyk \& Nefale 2005:49) - which lead to feelings of loneliness, hopelessness and anger and, very often, the person feels misunderstood (Ramirez 1999:1, 217). As a result many Africans define themselves by the finiteness of materialisation, bypassing deeper spiritual transformation.

Secularisation indeed confuses the world view of the traditional and modern African, leading to the problematic nature of divorcing life (religion) from life (society) ${ }^{6}$ and subsequently to moral failure (Senekoane 2013:319-332) or hitting 'the wall'. The sacred hitherto seems to become fragmented, even eroded. The tendency of presenting African spirituality as static calls our attention to the tidal process of reformation.

4.Rootlessness is understood to be "loss of heritage" (Gibson 2013:165).

5.In South Africa, the urban population will increase from 341686 in 2014 to 49103 in 2050. The United Nations predicts that $77 \%$ of the South African population will be urbanised by 2050 (United Nations 2014:21).

6.Society is seen as 'civilisation' - in other words, as the material and instrumental side of human culture (Senekoane 2013). 


\section{Tides and tendencies of reformation}

To illustrate the kinds of tidal differences that flow in South Africa and to build (or surf) upon the foundation of the centripetal and centrifugal tides or approaches, I will now briefly review the African reformation, that is, a new understanding of God, yourself and others followed by joy as contra-tide ${ }^{7}$ against deformation.

Reformation is a spiritual process in which the source experience and the changing circumstances of the time are creatively related to each other (Waaijman 2002:117). To accomplish the above, a desire for reversal is needed (Waaijman 2002:462), a U-turn back to the 'original orientation to God' (Waaijman 2002:462) which Hevi (2004:55), an African moral theologian, calls 'primeval innocence'. Reformation is not a foreign concept for Africa. It is already built into African spirituality in the form of a 'challenge for authenticity' or a recapturing of 'Sankofa' - the articulation and active promotion of African moral rebirth, in a moral and spiritual sense (Hevi 2004:41, 102). I am of the opinion that African spirituality's state of 'primeval innocence' corresponds with the transformation-stage reformation (aimed at the recovery of the original form of humans or the image of God) as described by Waaijman (2002:463, 514, 857). In the same vein, African theologian Ngong (2010:63, 147) describes and advocates for a reformation of the 'African Christian imagination' in order to rectify the fractured spiritual connection, namely:

to call society back to reverence what should be marked as sacred, to what needs honoring and commemorating, if the highest manifestations and ambitions of a culture are to be sustained. (Misztal 2003:67-84)

Everyday restoration of God's image per contra goes deeper and farther than the familiar. A respondent in a volunteer study displays how she is dissolved in and recreated by virtue of her 'new understanding of God' (Waaijman 2002:461, 463):

It took me until I was almost 50 years old to believe that, in God's wisdom, we all have different gifts, and that [if] I take the place of somebody else that should be there [and then] I as well as the people there don't get the best they can get. (Favor 2004:245)

Secondly, reformation occurs when a person begins to understand herself anew. Such a new understanding of self and self-worth is possible because of self-critique (Maluleke 2010:157). Self-criticism is a 'continuous willingness to be examined anew, and if necessary to be transformed in the light of Scripture' (Smit 2011:325). This self-understanding can make African spirituality deeply contextual. Rosado's (2008) observation is of note:

People's sense of self-worth, value and dignity is most often determined not only by the kind of support and encouragement they receive from others, but also from how willing they are to self-examine negative behaviors in their own life and in their cultural group. (p. 3)

7.A contra-tide is a tide that runs up (or down) with as much velocity as an opposing tide runs down (or up) (Davidson, O'Hare \& George 2009:30, 31; Moore 1887:24).
As soon as you get rid of your own dark spaces, you make space for the light. When you abandon the 'way of the world', the form of God is gaining a grip on you (Waaijman 2002:461). As soon as a person changes, her or his views and insights change. A self-critical attitude (semper reformanda) liberates believers from the view that structures and agents are established, permanent and unchangeable. Here is an example. Although a stipend-paid volunteer compensation is lower than any other job, one volunteer participates because of the effort that she invested in her volunteering tasks: 'I do my job with love, passion in return for growth in me like any other job I would have to do' (Hunter \& Ross 2013:755-756).

In the third place, reformation entails a new understanding of others. When you understand God anew your understanding of fellow human beings outside of the traditional is also transformed - because you are transformed. Lefu (female, township) reported:

I learn more to build my own self, to know what is wrong, what is right and which is which, ja. God has forgiven me, because if you are a child of God you have to accept each other, White, Black or coloured. (Brittian, Lewin \& Norris 2013:651)

Agbiji and Swart's (2015) encouragement is of note:

It is only when you are self-critical of your own negative conduct that you are able to renounce the opulence and greed of corporate entrepreneurs and politicians who play such crucial roles in the pauperization of Africans and African nations. By being self-critical Africans will be and become able to realize with integrity the moral values upheld by all religious traditions' (including the oral tradition of African Traditional Religion) namely virtue, justice, the sanctity of human life, equality and human dignity. (p. 14)

Why is reformation necessary? Reformation generates initiatives, opportunities and possibilities. Smit (2011) emphasises the importance of reformation and links it to self-critique:

The changing mentality of the times, namely a strong sense of social crisis and an awareness of the falling apart of the social order, and therefore the urgent need for new social order and reconstruction, plays a crucial role in the need for such a Reformed ethics - as will often again be the case in history, when social crises call for new and self-critical ethical projects. (p. 324)

Maluleke (1996:24) states that self-criticism as part of spiritual transformation 'is not only progressive it is to be encouraged and to be admired' because it leads to freedom'. Spiritual transformation can grow 'out of the deep personal experience of the fragmentary or broken character of life leading one to discover a power that can overcome the sense of incompleteness' (Stumpf 1966:422).

I briefly review the African reformation tides and tendencies, that is, a new understanding of God, oneself and others. I will now look at joy as another means of reformation and a contratide against deformation. I will track the dynamics of the 
African spiritual-based concept of joy, as a bridge to new possibilities.

\section{The contra-tide of joymotion}

In the search for transformation, African spirituality is often described as a spirituality of joy (Hevi 2004:100; Kalilombe 1994:129; Mbiti 2006:21-23) from the centrifugal to the centripetal. At the heart of this spirituality is the conviction that 'the enjoyment of life is part of living' (Masango 2006:930). Some regard this conviction as the summary of African spirituality. Firstly, it is the theme of Desmond Tutu's contribution in The Book of Joy (2016), then the basis of Hevi's 'The Spirit Set Free: African Spirituality in the Service of Hope and Joy' (2004), thirdly, it is the motif of life (Masango 2006:930), next, it is regarded as the subject in some African proverbs (Pobee 1997:49, 109), in the fifth place, it is one of the keys of African womenhood (Afotri 2004:95) and lastly it is reckoned as a source of fun (Oberholzer 2017). A focus on transformative capacity of joy in African spirituality is relatively new though, and an emphasis on the stage or movement from the centripetal (joy's personal transformative capacities) to the centrifugal is aux courant [up to date]. I will subsequently indicate the different transformational aspects of joy as a contra-tide against deformation. This article is, however, not advocacy for Transformational Psychology, Spiritual awakening or Transformative Learning Theory. Please refer to Taylor (2011; 2017), James (2013), Coe and Hall (2010), Mezirow and Taylor (2009) and Argyris and Schön (1996).

The 'joy' theme appears in different contexts giving rise to different transformative trajectories. In at least three such contexts, Africans open themselves up to all the different experiences that life has to offer. Firstly, at the heart of spiritual transformation, Africans deal with joy as an awareness of God. The enjoyment of life implicates the appreciation of life (Bhengu 1996:64) and the 'Transcendent Being' (Gehman 2005:354) that gives life. At the same time, emotions or the absence thereof 'convince people that they are wrong in their behavior and need to submit to the advice of the diviner, and follow the traditions of the ancestors' (Gehman 2005:29). Of special importance regarding awareness are the symbols of hair and colour. 'Five tufts' (of hair) symbol is said to be the Africa's antique hairstyle of joy, and represents the devotion and faithfulness one displays when doing a task required of one. Mpuannum means loyalty or the embodiment of lofty duty to a desired goal (Willis 1998). For Xhosas, red represents vanity and joy (Macleod 2002:13).

Secondly, joy is an orientation. Africans relate joy to God. 'God is joy' says Paynter (2003:176). It is the expression of the Spirit (Hevi 2004:100), and the conscious or unconscious experience of the Spirit sets you free when you experience and express inner freedom though spontaneous joy (Hevi 2004:100). Joy is for some simply the most and devotional description of the Christian life available.
They pray: 'May you, o Lord, be for us a moon of joy and happiness' (The Tablet 1998). For others, joy is a key element in African worship' (Zamarron 2013):

Everywhere in the world joy is the true expression of gratefulness. But not everywhere are the faces of God's children as transparent to that joy as in black Africa. (Steindl-Rast 1984:18)

Next, Africans have an influential understanding of joy as a generator. Joy converts spiritual energy into physical energy originally intended to transcend a particular context. During a very intense spiritual musical experience like drumming, Africans are carried out (concordant with spiritual centripetality) beyond themselves to find themselves (Dewey 1980:199). They encounter the divine through music (Oosthuizen 2016:8) and the drum is the chief activator (Spencer 1988:72). The drum is also a symbol of joy (Mbiti 2006:21), vibrating in the depths of the body and agitating the inner person to break out in praise of God and take action. When Africans hear the drum, they are reminded that 'all good things come ultimately from God, even the fruit of our labours' (Mbiti 2006:22). A drummer's inaudible cross rhythm (body movements) is the clue to the drummer's most subtle joy (Kubik 1962:40).

In the fourth place, the citing of relevant African proverbs in African congregations stirs the imagination and therefore better understanding. When they enjoy (Moon 2009:178), they remember and see themselves agreeing with the truth being proclaimed (Pobee 1997:54). It follows that joy is formative, cathargic and communal. Through dancing (as expression of gratitude, praise and joy in the presence of God), a person is strengthened spiritually (Oosthuizen 1976:21). Finally, joy's power lies in its reciprocity. Identity is no longer 'irreducible and anaemic, something that has to be clung to and ferociously asserted' (Ticciati 2013:47). Through joy, identity is experienced as 'guaranteed by God such that they need no longer to fight for it' (Ticciati 2013:47). Joy's expanding relationality becomes a means of reformation, a movement or contratide against deformation.

\section{The shifting sacred: The future is here}

Can a time of transition be a time of transformation alla Reisenberger (2002:9)? Can Africans journey from deformation through reformation to transformation? The content of the literature reviewed revealed that some literature about African spiritual transformation tends to focus on stagnation or the rights and abilities of the collective African. However, individual spiritual transformation is a means or way to redefine or establish what South Africans really stand for and are willing to uphold. Some Africans are already centripetal, dissolving in God and became transparent so that His light transforms communities. Others begin to acknowledge individuals (or communities) who play a leading and an active role in their own destiny (Kirsten 2004:7). Joy for 
them is an awareness, an orientation and a generator, a full engagement with life, weaving seamlessly together the material and the spiritual.

Because God accommodates Africans 'pulse of life' (Block 1949:233), their 'joymotions' can be accommodated or developed as sustainable transformative methodologies in meetings, classes, graduation ceremonies, sermons and lectures to spur the spiritual transformation that precedes social transformation. Spiritual centripetality of this nature (individual spiritual transformation, that is, individual responsibility before God and inspiration by God through joymotion) is not a focus on decolonisation as escapism transforming into verisimilitude. It is a possible vehicle or leads to centrifugal social action - a crown outcome of the current decolonisation debate. Africa has the ability to make themselves and the world rethink joy, helping all of us to understand an African spiritual centrifugality that says: 'I am because we are' and spiritual centripetality that says: 'We are because I am' (Dube 2006:151). It is not a revolution of structures by agents. It is a revolution of the heart by the Spirit.

\section{Conclusion}

The current dispensation and recent global tendencies have, to a large extent, predisposed and influenced how Africans perceive transformation in South Africa. A compelling conclusion is that there is a need to reassess institutionalised transformation because tidal pool thinking can result in losing opportunities. The institutionalisation of transformation in South Africa, in short, requires a much more nuanced understanding of transformation because 'context counts' (Brown 2010:183). Secondly, this literature review has provided an insight into the context and reality of a fracturing society on a multitude of levels. Nevertheless, all is not lost. Transformation of a society does not happen in a spiritual vacuum. Examining the outer horizon in South Africa, spiritual transformation is established as a sui generis [unique] aspect of African spirituality. African spirituality is the very air citizens breathe in. A third key conclusion is that although African spirituality seems to be full of ambiguity and fragmentedness, incongruent and inconsistent, it is not stagnant, a quick fix and definitely not permanent. It is dynamic and processual. As the tide ebbs, it leaves the shallows and takes with it old ideas and beliefs. The incoming tide or movement brings new concepts and surprising experiences.

Perhaps what policymakers should consider then is that transformation is also spiritual - not results, but processes; not a method, a structure or an agent, but a generator; and not permanence, but transformation in evolving concepts. A transformation agenda should appreciate and understand the construct of different people being on different journeys and in different stages, movements and tides in their journeys. Spiritual transformation is and can lead Africans towards a new spirituality. Joy is one of its surfboards.

\section{Acknowledgements Competing interests}

The author declares that he has no financial or personal relationships which may have inappropriately influenced him in writing this article.

\section{References}

Aburdene, P., 2005, Megatrends 2010: The rise of conscious capitalism, Hampton Roads Publishing, Charlottesville, VA.

Afotri, D.D., 2000, 'African womanhood and conflict resolution', African Renaissance $1(3), 95-99$.

Agbiji, O.M. \& Swart, I., 2015, 'Religion and social transformation in Africa: A critical and appreciative perspective', Scripture 114, 1-20. https://doi.org/10.7833/114-01115

Appadurai, A. \& Breckenridge, C.A., 2008, 'Afterword: The risk of Johannesburg', in S. Nuttall \& A. Mbembe (eds.), Johannesburg: The Elusive Metropolis, pp. 351-354 Duke University Press, New York.

Argyris, C. \& Schön, D.A., 1996, Organizational learning II: Theory, method and practice, Addison Wesley Publishing Company, Boston, MA.

Ashforth, A., 2000, Madumo, a man bewitched, University of Chicago Press, Chicago, IL.

Atkinson, P.W. \& O'Brochta, D.A., 2000, 'Hermes and other hAT elements as gene vectors in insects', in A.M. Handler \& A.A. James (eds.), Transgenesis: Methods and applications, pp. 219-236, LLC Press, Boca Raton, FL.

Beliveau, E.M., 1988, 'Transformation of an institution: The design of a Catholic Church for Boston's south end', Master of Architecture Degree, Massachusetts Institute of Technology, Cambridge, MA.

Bender, G., 2008, 'Exploring conceptual models for community engagement at higher education institutions in South Africa', Perspectives in Education 26(1), 81-95.

Bertelsmann Stiftung BTI 2016, 2016, South Africa country report, Bertelsmann Stiftung, Gütersloh.

Bhengu, M.J., 1996, Ubuntu: The essence of democracy, Novalis Press, Cape Town.

Block, E., 1949, The three years, Verlag: Urauchhaus, Stuttgart.

Boswell, R., 2016, 'Race must fall: The politics of heritage, race and identity in South Africa', Paper presented at EASA (European Association of Social Anthropologists) 2016 Anthropological Legacies and Human Futures Conference, University of Milano-Bicocca, Milan, viewed 18 December 2016, from http://nomadit.co.uk/ easa/easa2016/panels.php5?PanelID=4443

Brittian, A., Lewin, N. \& Norris, S.A., 2013, 'You must know where you come from: South African youths' perceptions of religion in time of social change', Journal of Adolescent Research 28(6), 642-663. https://doi.org/10.1177/0743558413480834

Brown, J., 2010, 'Assuming too much? Participatory water resource governance in South Africa', The Geographical Journal 177(2), 171-185. https://doi. org/10.1111/j.1475-4959.2010.00378.x

CANSA, 2016a, Community mobiliser, CANSA, Bedfordview.

CANSA, 2016b, CANSA vacancy-Community mobiliser fund development (Bethlehem), CANSA, Bedfordview, viewed 18 December 2016, from http://www.cansa.org.za/ cansa-vacancy-community-mobiliser-fund-development-bethlehem/

Carrim, N.M.H. \& Nkomo, S.M., 2016, 'Wedding intersectionality theory and identity work in organizations: South African Indian women negotiating managerial work in organizations: South African Indian women negotiating managerial
identity', Gender, Work and Organisation 23(3), 261-277. https://doi.org/ identity', Gender, Work
10.1111 /gwao.12121

Chipkin, I., 2008, 'Set-up for failure: Racial redress in the Department of Public Service and Administration', in A. Habib \& K. Bentley (eds.), Racial redress and citizenship, pp. 129-151, HSRC Press, Cape Town.

Chung, T.C. \& Sawyer, C., 2008, 'The trinity encounter and all that Jazz. Can Jazz transform us Spiritually?', in A.D. Abernethy (ed.), Worship that changes lives: Multidisciplinary and congregational perspectives on spiritual transformation (engaging worship), pp. 131-148, Baker Publishing Group, Grand Rapids, MI.

Cilliers, J. \& Nell, I.A., 2011, 'Within the enclave - Profiling South African social and religious developments since 1994', Verbum Et Ecclessia 32(1), 1-7. https://doi. org/10.4102/ve.v32i1.552

Clarke, M. \& Basset, C., 2016, 'The struggle for transformation in South Africa: Unrealised dreams, persistent hopes', Journal of Contemporary African Studies 34(2), 183-189. https://doi.org/10.1080/02589001.2016.1202501

Coe, J.H. \& Hall, T.W., 2010, Psychology in the spirit: Contours of a transformational psychology, Intervarsity Press, Downers Grove, IL.

Conradie, E. \& Pillay, M., 2015, 'On the dynamism of reform movements', in E. Conradie \& M. Pillay (eds.), Ecclesial reform and deform movements in the South African context, EFSA (Ecumenical Foundation of Southern Africa), pp. 7-10, SUN Media, context, EFSA

Davidson, M.A., O'Hare, T.J. \& George, K.J., 2009, 'Tidal modulation of incident wave heights: Fact or Fiction?', Reef Journal 1(1), 16-32.

Department of Education, 2002, Revised national curriculum statement grades $R-9$ (schools), Government Printer, Pretoria.

Department of Education South Africa, 1997, Education white paper 3. A programme for higher education transformation, Government Gazette No. 18207, 15 August 1997, Government Printers, Pretoria. 
Department of Tourism, 2016, Strategic plan 2015/16-2019/20 (2016/17 review), Department of Tourism, Pretoria.

Desai, A., 2008, 'Citizenship and cosmopolitanism: Football in South Africa', in A. Habib \& K. Bentley (eds.), Racial redress and citizenship, pp. 259-272, HSRC Press, Cape Town.

Dewey, J., 1980, Art as experience, Capricorn Books, New York.

Dornan, J.L., 2002, 'Agency and archaeology: Past, present, and future directions', Journal of Archaeological Method and Theory 9(4), 303-329. https://doi org/10.1023/A:1021318432161

DPSA (Department of Public Service and Administration), Republic of South Africa, 1997, The white paper on transforming the public service delivery, Government Printers, Pretoria.

Dube, M.W., 2006, 'Adinkra! Four hearts join together. On becoming healing-teachers of African Indigenous religion/s in HIV \& AIDS prevention', in M.A. Oduyoye, I.A Phiri \& S. Nadar (eds.), African women, religion, and health: Essays in Honor of Phiri \& S. Nadar (eds.), African women, religion, and health: Essays in
Mercy Amba Ewudziwa Oduyuye, pp. 131-156, Orbis Books, New York.

Dyrness, W., 2008, 'Transformation and the visual arts: A protestant methodological inquiry into imagery and worship', in A.D. Abernethy (ed.), Worship that changes lives: Multidisciplinary and congregational perspectives on spiritual transformation (engaging worship), pp. 101-114, Baker Publishing Group, Grand transformatior

Eggleston, P. \& Zhao, Y., 2000, 'Targeted transformation of the insect genome', in A.M. Handler \& James, A.A. (eds.), Insect transgenesis: Methods and applications, pp. 29-52, LLC Press, Boca Raton, FL.

Falk, R., 2001, Religion and humane global governance, Palgrave, New York.

Farley, T., 2008, 'Worship, dramatic arts and the agogic moment', in A.D. Abernethy (ed.), Worship that changes lives: Multidisciplinary and congregational perspectives on spiritual transformation (engaging worship), pp. 61-80, Bake Publishing Group, Grand Rapids, MI.

Favor, C.A., 2004, 'Relational spirituality and social caregiving', Social Work 49(2), 241-249.https://doi.org/10.1093/sw/49.2.241

Froise, H., 2005, 'Religious dualism in South Africa: Consequences of inadequate mission theology of the spirit world', PhD. thesis, University of the Free State, mission theology
Bloemfontein.

Gehman, R.J., 2005, African traditional religion in biblical perspective, East African Educational Publishers, Nairobi.

Gibson, N.J., 2013, 'Skeletal (in-)visibilities in the city - Rootless: A video sculptura response to the disconnected in Cape Town', South African Theatre Journal 26(2), 151-171. https://doi.org/10.1080/10137548.2012.839097

Grant, T., 2007, 'Transformation challenges in the South African workplace: A conversation with Melissa Steyn of iNCUDISA', Business Communication Quarterly 70(1), 93-98. https://doi.org/10.1177/108056990707000117

Gumede, V., 2016, 'The South Africa we do not want to know', Mail \& Guardian, viewed 18 December 2016, from http://thoughtleader.co.za/vusigumede/2016/07/13/ the-south-africa-we-do-not-want-to-know/comment-page-1/

Harless, J.T., 2012, 'Transformational discipleship: A model for sermon-based small groups for life transformation', Doctor of Ministry thesis, Liberty Baptist Theological Seminary, Lynchburg, VA.

Hevi, J.K., 2004, The challenge of authenticity: African culture and faith commitment, Adonis \& Abbey Publishers Ltd., London.

Higgins, J. \& Vale, P., 2016, 'State of urgency', Arts and Humanities in Higher Education 15(1), 3-6. https://doi.org/10.1177/1474022215618512

Hoppers, A.O., 2012, Development education, University of South Africa, Pretoria, South Africa.

Hoppers, C.A.O., 2010, 'Renegotiating agency in knowledge production, innovation and Africa's development in the context of the triage society', Critical Literacy: Theories and Practice 4(1), 78-94.

Huls, J., 2006, 'Mystagogy in primordial spirituality as perspective for African spiritualities', St. Augustine College 7(1/2), 54-72.

Hunter, K. \& Ross, E., 2013, 'Stipend-paid volunteers in South Africa: A euphemism for low-paid work?', Development Southern Africa 30(6), 743-759. https://doi.org/1 0.1080/0376835X.2013.860014

Idang, G.E., 2015, 'African culture and values', Phronimon 16(2), 97-111.

Iten, K., 2016, 'Special feature: Transformation', Accountancy Journal, 7 August 2016 viewed 27 October 2017, from http://www.accountancysa.org.za/wordpress/ special-feature-transformation/

James, W., 2013, The varieties of religious experience, Dover Publications, Inc., New York.

Jili, N.N., 2012, 'The perceptions of youth on service delivery violence in Mpumalanga Province', Master's Degree in Public Administration (MPA), University of Zululand, Durban.

Johnston, R., 2008, 'Rated "R" for mystery: Worship lessons learned from the movies', in A.D. Abernethy (ed.) Worship that changes lives: Multidisciplinary and congregational perspectives on spiritual transformation (engaging worship), pp. 115-130, Baker Publishing Group, Grand Rapids, MI.

Jones, S., 2000, 'Discourses of identity in the interpretation of the past', in J. Thomas (ed.), Interpretive archaeology: A reader, pp. 445-457, Leicester University Press, London.

Kalilombe, P.A., 1994, 'Spirituality in African perspective', in R. Gibellini (ed.), Paths of African theology, pp. 115-135, Orbis Books, New York.

Kappler, S., 2015, 'The dynamic local: Delocalisation and (re-)localisation in the search for peacebuilding identity', Third World Quarterly 36(5), 875-889.https://doi.org/ 10.1080/01436597.2015.1025740
Kelkil, F.T., 2015, 'Civil society organisations and societal transformation in Africa: The case of Ethiopia', PhD thesis, University of South Africa, Pretoria.

Kilde, J.H., 2002, When church became theatre: The transformation of evangelical architecture and worship in nineteenth-century America, Oxford University Press, Oxford.

Kirsten, I., 2004, 'Spirituality as dimension of integrated community development: Practical application', Paper presented at the NACSW Convention, Sheraton Reston Hotel, Reston, VA, 28-31th October.

Knoetze, J.J., 2015, 'Spiritual transformation: Reaching and equipping sub-Saharan African children', In die Skriflig 49(1), Art. \#1919, 1-8, viewed 29 December 2016, from http://www.indieskriflig.org.za/index.php/skriflig/articleview/1919/3238

Knoop, H.H. \& Fave, A.D., 2013, Wellbeing and cultures. Perspectives from positive psychology, Springer Science and Business Media, Dordrecht.

Krige, D., 2015, "'Growing up" and "moving up": Metaphors that legitimise upward social mobility in Soweto', Development Southern Africa 32(1), 104-117. https:// doi.org/10.1080/0376835X.2014.975337

Kubik, G., 1962, 'The phenomenon of inherent rhythms in East and Central African instrumental music', Phenomenon of Inherent Rhythms. African Music 1(3), 33-42.

Kumaran, M., Samuel, N. \& Winston, L., 2012, 'The NGO sector in South Africa: History, issues and prospects', Journal for Development and Leadership 2, 31-46.

Lama, D. \& Tutu, A.D., 2016, The book of joy, Hutchinson, London.

Letsekha, T., 2013, 'Revisiting the debate on the Africanisation of higher education: an appeal for a conceptual shift', The Independent Journal of Teaching and Learning $8,5-7$.

Lombaard, C., 2012, The Old Testament and Christian spirituality: Theoretical and practical essays from a South African perspective, Society of Biblical Literature, Atlanta, GA.

Lombaard, C., 2015, 'Biblical spirituality and transformation', In die Skriflig 49(2), Art. \#1950, 1-6, viewed 29 December 2016, from http://www.indieskriflig.org.za/ index.php/skriflig/article/view/1950/3337

Mabokela, R.O., 2012, 'Negotiating race and gender identity in the knowledge age: The case of South African universities', in B. Pusser, K. Kempner, S. Marginson \& I. Ordorika (eds.), Universities and the public sphere: Knowledge creation and state building in the era of globalization, pp. 121-138, Routledge, New York.

MacDonald, D.A., 2010, "Ubuntu bashing: The marketisation of "African values" in South Africa', Review of African Political Economy 37(124), 139-152. https://doi. org/10.1080/03056244.2010.483902

Macleod, G., 2002, Cultural considerations in South African business. A guide to understanding culture, courtesy and etiquette in South African business, Spearhead, Claremont, CA.

Magesa, L., 1998, African religion: The moral traditions of abundant life, Paulines Publications, Nairobi.

Makhanya, M.S., 2011, Launch of the UNISA charter of transformation 27 June 2011 viewed 28 October 2017, from http://www.unisa.ac.za/static/corporate_web/ Content/About/Executive $\% 20$ management/Unisa $\% 20$ Principal $\% 20$ and $\% 20$ Vice-Chancellor/documents/PROF_MAKHANYA CharterLaunchAddress.pdf

Makhubela, M., 2016, "From psychology in Africa to African psychology": Going nowhere slowly', PINS (Psychology in Society) 52, 1-18. https://do org/10.17159/2309-8708/2016/n52a1

Maluleke, T.S., 1996, 'African culture, African intellectuals and the white academy in South Africa - Some implications for Christian theology in Africa', Religion and Theology 3(1), 19-42.

Maluleke, T.S., 2010, 'A postcolonial South African church: Problems and promises', in D.B. Stinton (ed.), African theology on the way: Current conversations, pp. 150-160, SPCK, London.

Masango, M.J.S., 2006, 'African spirituality that shapes the concept of Ubuntu', Verbum at Ecclesia 27(3), 930-943.https://doi.org/10.4102/ve.v27i3.195

Mattes, R., 2004, Understanding identity in Africa: A first cut, Working Paper No. 38, The Afrobarometer Network, Cape Town.

Mbigi, L. \& Maree, J., 1995, Ubuntu: The spirit of African transformation, Management Knowledge Resources, Pretoria.

Mbiti, J., 2006, 'Aspects of African heritage and spirituality', St. Augustine College 7(1/2), 107-116.

Mezirow, J. \& Taylor, E.W., 2009, Transformative learning in Action: A handbook for practice, Jossey-Bass, San Francisco, CA.

Misztal, B.A., 2003, Theories of social remembering, Open University Press, Maidenhead, Berkshire, England.

Mokgoro, Y., 1998, Ubuntu and the law in South Africa, Potchefstroom Electronic Law Journal 1(1), 1-11, viewed 28 May 2018, from http:www.puk.ac.za/opencms/ export/PUK/html/fakulteite/regte/per/issuepages/1998Volume1no1/1998x 1x_Mokgoro_sum.pdf

Moon, W.J., 2009, African proverbs reveal Christianity in culture: A narrative portrayal of Builsa proverbs contextualizing Christianity in Ghana, Pickwick Publications, Eugene, OR.

Mooney, R.T.J., 2014, Like a child: Restoring the awe, wonder, joy and resiliency of the human spirit, SkyLight Paths Publishing, Woodstock, VT.

Moore, J.H., 1887, The coaster's companion: Containing directions for the downs, for sailing, MESSRS. Robinson and John Hamilton Moore, London.

Morris, M.W., Leung, K., Ames, D. \& Lickel, B., 1999, 'Views from inside and outside: Integrating emic and etic insight about culture and justice judgment', Academy of Management Review 24, 781-796. 
Morrow, S., 2008, 'Race, redress and historically black universities', in A. Habib \& K. Bentley (eds.), Racial redress and citizenship, pp. 263-288, HSRC Press, Cape Town.

Mosha, S., 2000, The heartbeat of indigenous Africa: A study of the Chagga Educational System, Garland Publishing Inc., New York.

Mugambi, J.N.K., 1995, From liberation to reconstruction: African Christian theology after the cold war, East African Educational Publishers, Nairobi.

Mugisha, M., Ojok, D., Kiranda, Y. \& Kabasa, B.B., 2016, 'Youth participation in political processes in Uganda: Exploring opportunities and constraints', Journal of International Affairs 7(1-2), 55-61.

Murithi, T., 2006, 'African approaches to building peace and social solidarity', African Journal on Conflict Resolution 6(2), 9-33.

Muto, S., 2011, 'The unfolding project: Science, anthropology and the theology of human and Christian formation', Journal of Spiritual Formation \& Soul Care 4(1), 93-104. https://doi.org/10.1177/193979091100400106

Mwombeki, F.R., 2001, 'Reading the bible in contemporary Africa', Word and World 21(2), 121-128.

Mzondi, A.M.M., 2014, 'The end of essentialist gods and Ubuntu: A feminist critical investigation', PhD thesis, University of Johannesburg, Johannesburg.

Naidoo, V., 2008, 'Assessing racial redress in the public service', in A. Habib \& K. Bentley (eds.), Racial redress and citizenship, pp. 99-128, HSRC Press, Cape Town.

National Treasury Republic of South Africa, 2017, The budget review 2017, National Treasury Republic of South Africa, Pretoria.

Nauta, W., 2004, The implications of freedom: The changing role of land sector NGO in a transforming South Africa, LIT Verlag, Munster.

Neocosmos, M., 2006, 'Can a human rights culture enable emancipation? Clearing some theoretical ground for the renewal of a critical sociology', South African Review of Sociology 27(2), 356-379. https://doi.org/10.1080/21528586.2006.1 0419163

Ngong, D.T., 2010, Imagining a more hopeful future for Africa, Peter Lang Publishing Inc., New York.

Nurnberger, K., 2007, The living dead and the living God, Cluster Publications, Pietermaritzburg.

Oberholzer, E., 2017, Watch: SA Granny dancing and singing along to Gobisiqolo, 2017, Video recording, Featuring Maureen Craig, viewed 28 October 2017, from https://www.thesouthafrican.com/granny-dancing-singing-gobisiqolo/

Odoyuye, M., 1999, 'A coming home to myself: The childless woman in the WestAfrican space', in M.A. Farley \& S. Jones (eds.), Liberating eschatology: Essays in Honour of Letty M. Russell, pp. 105-122, Westminster John Knox Press, in Honour of
Louisville, KY.

Oosthuizen, G.C., 1976, The Theology of a South African Messiah, E. J. Brill, Leiden, Köln.

Oosthuizen, R.D., 2016, 'The drum and its significance for the interpretation of the Old Testament from an African perspective: Part two', Verbum at Ecclessi 37(1), viewed 30 December 2016, from http://www.scielo.org.za/pdf/vee/ v37n1/38.pdf

Paynter, N., 2003, Blessed be our table: Graces for mealtimes and reflections on food, Wild Goose Publications, Glasgow.

Pieterse, M., 2005, 'What do we mean when we talk about transformative constitutionalism?', SA Publiekreg=SA Public Law 20(1), 155-166.

Pobee, J.S., 1997, 'Proverbs and African Christianity', Paper presented at the Consultation on African Proverbs and Christian Mission at Ricatla Theological Seminary, Ricatla Theological Seminary, Maputo, Mozambique, 27-31th March.

Potgieter, C. \& Moleko, A.S., 2004, 'Stand out, stand up, move out: Experiences of black South African women at historically white universities', in R.O. Mabokela \& Z. Magubane (eds.), Hear our voices: Race, gender and the status of black South African women in the academy, pp. 80-95, University of South Africa Press, Pretoria.

Ragin, A., Farley, T. \& Hoye, J., 2008, 'Dance and transformation: Praising through brokenness to holiness in worship', in A.D. Abernethy (ed.), Worship that changes lives: Multidisciplinary and congregational perspectives on spiritual transformation (engaging worship), pp. 81-100, Baker Publishing Group, Grand Rapids, MI.

Rahner, K., 1984, Foundations of Christian faith: An introduction to the idea of Christianity, Crossroad Publishing Company, New York.

Ramirez, M., III., 1999, Multicultural psychotherapy. An approach to individual and cultural differences, Allyn \& Bacon, Boston, MA.

Ramphele, M., 2008, Laying ghosts tor: Dilemmas of the transformation in South Africa, Tafelberg Publishers, Cape Town.

Reisenberger, A.T., 2002, 'Prologue', in A.T. Reisenberger (ed.), Women's spirituality in the transformation of South Africa, pp. 9-16, Waxmann Verlag GmbH, Münster.

Rosado, C., 2008, What do we mean by 'managing diversity'?, viewed 28 July 2018, from http://www.edchange.org/multicultural/papers/rosado_managing_ diversity.pdf

SACC (South African Council of Churches), 2017, The South Africa we pray for 2011 2015, South African Council of Churches, Johannesburg, viewed 27 October 2017 from http://sacc.org.za/about/campaigns/the-south-africa-we-pray-for/

Sachs, A., 1992, Advancing human rights in South Africa, Oxford University Press, Cape Town.

Sapir, E., 1963, Languages, Rupert Hart-Davis, London.
Schierup, C., 2016, 'Under the rainbow: Migration, precarity and people power in post-apartheid South Africa', in M.B. Jørgensen \& C. Schierup (eds.), Politics of precarity: Migrant conditions, struggles and experiences, pp. 276-316, Koninklijke precarity: Migrar
Brill, Leiden.

Schulz-Herzenberg, C., 2009, 'Towards a silent revolution? South African voters during the first years of democracy 1994-2006', PhD thesis, University of Cape Town, the first yeaps
Cape Town.

Senekoane, B.B., 2013, 'The problematic nature of divorcing life from life', Studia Historiae Ecclesiasticae 39(2), 319-332.

Sigger, D.S., Polak, B.M. \& Pennink, B.J.M., 2010, Ubuntu' or 'humanness' as a management concept, CDS Research Report No. 29, University of Groningen, Groningen.

Smit, D., 2011, 'Trends and directions in reformed theology', The Expository Times 122(7), 313-326. https://doi.org/10.1177/0014524610394617

Somni, S.H. \& Sandlana, N.S., 2014, 'Reframing and defining family therapy: Ubuntu perspective', Paper presented at the 1st International Congress of Forum of African Psychology, University of Limpopo, Polokwane, 27-29th March.

Spenceley, A. \& Goodwin, H., 2007, 'Nature-based tourism and poverty alleviation: Impacts of private sector and parastatal enterprises in and around Kruger National Park, South Africa', Current Issues in Touris 10(2\&3), 255-277. https:// doi.org/10.2167/cit305.0

Spencer, J.M., 1988, 'Rhythm in black religion of the African Diaspora', Journal of Religious Thought 44(2), 67-82.

Spies, C., 2010, 'Intrapslag: 'n storm broei', Die Burger, 25 September, p. 14.

Steenkamp-Nel, A., 2018, 'Shifting landscapes: Spirituality in the life of the African healthcare volunteer', in A. de la Porte, N. Joubert \& A. Oberholzer (eds.) Proceedings of the 2nd Biennial South African Conference on Spirituality and Healthcare, pp. 261-277, Cambridge Scholars Publishing, Newcastle, UK.

Steindl-Rast, D., 1984, Gratefulness, the heart of prayer: An approach to life in fullness, Paulist Press, New York.

Stetzer, E. \& Rainer, T.S., 2010, Transformational church: Creating a new scorecard for congregations, B\&H Publishing Group, Nashville, TN.

Stevenson, A., 2010, Oxford Dictionary of English, 3rd edn., Oxford University Press, Oxford.

Stumpf, S.E., 1966, Socrates to Sartre. A history of philosophy, McGraw-Hill, New York.

Swartz, E. \& Davies, R., 1997, 'Ubuntu - The spirit of African transformation management - A review', Leadership \& Organization Development Journal 18(6), 290-294. https://doi.org/10.1108/01437739710176239

Taylor, S., 2011, Out of the darkness: From turmoil to transformation, Hay House, Kensington, London.

Taylor, S., 2017, The leap: The psychology of spiritual awakening, Hay House, Witkoppen.

Tesagaye, F.M. \& Sewenet, A.M., 2017, 'The role of art in mental decolonization', Imperial Journal of Interdisciplinary Research (IJIR) 3(6), 345-354.

Theletsane, K.I., 2012, 'Ubuntu management approach and service delivery', The Journal of Public Administration 47(1), 265-278.

The Tablet, 1998, 'The Living Spirit', The Tablet, 03 October, viewed 01 August 2018, from http://www.thetablet.co.uk/the-living-spirit

Thomas, C.G., 2009, 'Ubuntu. The missing link in the rights discourse in postapartheid transformation in South Africa', International Journal of African Renaissance Studies - Multi-, Inter- and Transdisciplinarity 3(2), 39-62. https:// doi.org/10.1080/18186870902840333

Three Initiates, 1912, The Kybalion. A study of the hermetic philosophy of ancient Egypt and Greece, The Yogi Publication Society Masonic Temple, Chicago, IL, viewed 28 October 2017, from http://www.hermetics.org/pdf/ kybalion.pdf

Ticciati, S., 2013, 'Theology in the second person', in A.T. Lincoln, J.G. McConville \& L.K. Pietersen (eds.), The Bible and spirituality. Exploratory essays in reading scripture spiritually, pp.38-55, Cascade Books, Eugene, OR.

Tlhagale, B., 2011, 'Faith and secularism - An African perspective', St. Augustine College 12(2), 3-25.

Tobler, J., 2002, 'Goddesses and women spirituality: Transformative symbols of the feminine in Hindu religion', in A.T. Reisenberger (ed.), Women's spirituality in the transformation of South Africa, pp. 51-72, Association for the Study of Religion, New York.

Travis, S., 2014, Decolonizing preaching: Decolonizing preaching the pulpit as postcolonial space, Cascades Books, Eugene, OR.

Tutu, D.M., 1999, No future without forgiveness, Doubleday, New York.

United Nations, 2014, World urbanization prospects. The 2014 revision, United Nations, New York.

United Nations Development Programme, 2003, South Africa human development report 2003. The challenge of sustainable development in South Africa: Unlocking people's creativity, Oxford University Press, Oxford.

Van den Hoogen, T., 2011, A taste of God: On spirituality and reframing foundationa theology, LIT Verlag, Berlin.

Van der Linde-de Klerk, M., Martin, N. \& de Beer, M., 2014, 'The development of a change agent identification framework for South African change agents', South African Journal of Labour Relations 38(1), 93-115.

Van Dyk, G.A.J \& Nefale, M.C., 2005, 'The split-ego experience of Africans: Ubuntu therapy as a healing alternative', Journal of Psychotherapy Integration 15(1), 48-66. https://doi.org/10.1037/1053-0479.15.1.48 
Van Wyk, M.M., 2017, "Exploring the role of the church as a "reformation agency" in enhancing a socially transformative agenda in South Africa', HTS Teologiese in enhancing a socially transformative agenda in South Africa', HTS Teologiese
Studies/Theological Studies 73(3), a4356. https://doi.org/10.4102/h ts.v73i3.4356

Vilakati, M.V., Shcurink, W. \& Viljoen, R., 2013, Exploring the concept of African spiritual consciousness, Academy of Management, Orlando, FL.

Waaijman, K., 2002, Spirituality: Forms, foundations, structures, Peeters, Leuven.

Waaijman, K., 2006, 'Conformity in Christ', Acta Theologica 27(8), 41-53.

Waaijman, K., 2007, 'Spirituality - A multifaceted phenomenon. Interdisciplinary explorations', Studies in Spirituality 17, 1-113.https://doi.org/10.2143/SIS.17.0. 2024643

Waghid, Y., 2002, 'Knowledge production and higher education transformation in South Africa: Towards reflexivity in university teaching, research and community service', Africa: Towards reflexivity in university teaching, research and community servition
Higher Education 43, 457-488. https://doi.org/10.1023/A:1015211718131
Willis, W.B., 1998, The Adinkra dictionary. A visual primer on the language of Adinkra, Pyramid Complex, Washington, DC.

Woodhead, L., 2007, 'Why so many women in holistic spirituality? A puzzle revisited', in K. Flanagan \& P.C. Jupp (eds.), A sociology of spirituality, pp. 115-125, Ashgate Publishing Limited, Hampshire.

Working Group on The Independent Code of Governance for Non-profit Organisations in South Africa, 2012, The independent code of governance for non-profit organisations in South Africa, Working Group on The Independent Code of Governance for Non-profit Organisations in South Africa, Cape Town.

Yontef, G.M., 1993, Awareness, dialogue \& process: Essays on gestalt therapy, The Gestalt Journal Press Inc., Gouldsboro, ME.

Zamarron, R., 2013, 'Joy, tradition, African culture in liturgy', National Catholic Register, viewed 29 December 2016, from http//www.ncregister.com/blog/ rachel-zamarron/joy-tradition-african-culture-in- 